\title{
Could a residential wood ash recycling programme be part of the solution to calcium decline in lakes and forests in Muskoka (Ontario, Canada)?
}

\author{
Shakira S.E. Azan ${ }^{a b \star}$, Norman D. Yan ${ }^{a b}$, Martha P. Celis-Salgado ${ }^{c}$, Shelley E. Arnott ${ }^{d}$, James A. Rusak ${ }^{e}$, \\ and Peter Sutey ${ }^{\mathrm{e}}$ \\ ${ }^{a}$ Department of Biology, York University, 4700 Keele Street, Toronto, ON M3J 1P3, Canada; ${ }^{b}$ Friends of \\ the Muskoka Watershed, P.O. Box 416, Bracebridge, ON P1L 1T7, Canada; ${ }^{c}$ FLAMES Laboratory, Dorset \\ Environmental Science Centre, Queen's University, 1026 Bellwood Acres Road, P.O. Box 39, Dorset, ON \\ P0A 1E0, Canada; 'Department of Biology, Queen's University, 116 Barrie Street, Kingston, ON K7L 3J9, \\ Canada; ${ }^{e}$ Dorset Environmental Science Centre, 1026 Bellwood Acres Road, P.O. Box 39, Dorset, ON \\ P0A 1E0, Canada \\ *shakira@fotmw.org
}

\begin{abstract}
One possible solution to the recent decline of calcium (Ca) concentrations in Canadian Shield forests and lakes in eastern North America is the addition of Ca-rich wood ash to watersheds. We investigated the feasibility of using small, mainly residential sources of non-industrial wood ash (NIWA) for this purpose by quantifying concentrations of its major nutrients and metals, its toxicity to Daphnia in aqueous extracts, and estimating the amount of NIWA available in the District of Muskoka in central Ontario. Locally collected NIWA averaged 30\% Ca, and also contained smaller but significant amounts of $\mathrm{K}, \mathrm{Mg}, \mathrm{Na}$, and $\mathrm{P}$. Of these, $\mathrm{K}$ was so soluble that it was toxic to Daphnia over $48 \mathrm{~h}$ in the concentrate and 10-fold dilution; however, sedimented ash was not toxic over $15 \mathrm{~d}$. Most metal levels in NIWA were below targets permitting unrestricted land application. However, $\mathrm{Cu}$ and $\mathrm{Zn}$ were just above these targets, but well below those for conditional use. Muskoka residents generate about $235000 \mathrm{~kg}$ of NIWA annually, not enough to treat all central Ontario areas affected; however, a NIWA recycling programme implemented across southern Ontario could generate enough ash to solve the Ca decline problem in Muskoka's forests and lakes.
\end{abstract}

Key words: calcium decline, Muskoka, wood ash, forests, Daphnia, recycling

\section{Introduction}

Calcium (Ca) concentrations have fallen in forest soils in eastern North America following decades of atmospheric acid deposition (Likens et al. 1998; McLaughlin 2014). Falling Ca levels in soils have reduced growth (Watmough 2002; Gavin et al. 2009; Bishop et al. 2015), health and vigour (Hallett et al. 2006; Long et al. 2009), seedling survival and regeneration (Cleavitt et al. 2011; Sullivan et al. 2013), and foliar nutrition (Bailey et al. 2004; Long et al. 2009; Miller and Watmough 2009) of sugar maple (Acer saccharum Marsh, 1785). In lakes, Ca decline has damaged populations of crayfish (Edwards et al. 2009; Hadley et al. 2015) and several species of Daphnia (Jeziorski et al. 2008), with consequences for pelagic food webs (Jeziorski et al. 2012, 2015; Korosi et al. 2012). 
Despite reductions in acid deposition, the natural recovery rate of Ca will be extremely slow (Likens et al. 1996; Aherne et al. 2003; Watmough and Aherne 2008); hence, adding Ca as a crushed mineral or wood ash to forested watersheds is an attractive option. Calcite additions have certainly improved chemistry and biota in acidified lakes (Yan et al. 1996), soil chemistry (Driscoll et al. 1996; Geary and Driscoll 1996; Löfgren et al. 2006), and forest health, regeneration, and productivity (Wilmot et al. 1996; Moore and Ouimet 2010, 2014; Mainwaring et al. 2014). However, limestone must be mined and shipped to areas of need. Large doses could also destabilize forest ecosystems (Lawrence et al. 2016), and limestone contains no plant nutrients other than Ca. Thus, wood ash is a promising alternative Ca source.

Industrial sources of wood ash are common. Canadian pulp and paper mill boilers alone produced up to 0.75 million tonnes of wood ash annually in 2002 (Elliott and Mahmood 2006), and it can increase soil $\mathrm{pH}$, foliar $\mathrm{Ca}$, tree growth, and overall forest productivity when nitrogen is not limiting (Augusto et al. 2008; Pugliese et al. 2014; Reid and Watmough 2014). Non-industrial wood ash (NIWA) (e.g., from homes and wood-fired pizza bakeries) is also an alternative and 18000 tonnes of wood ash are generated from residences in Ontario annually (Azan 2017). However, unlike industrial wood ash, the use of NIWA to ameliorate Ca limitation in forest soils and indirectly, downstream lakes, has not been studied, and it does pose issues that differ from industrial ash sources. Its composition, including its contaminant levels, might be more variable than industrial ash sources, given the variety of tree species and tree parts burned, the lack of consistent feedstock control, and differences in nonindustrial versus industrial combustion and ash processing. We do not know if NIWA would pass government guidelines for metal contaminants (Hannam et al. 2016), and the potential toxicity of NIWA has not been evaluated. Finally, the methods for safe and efficient collection, transport, and distribution of NIWA have not been developed, but they would clearly differ from industrial ash sources.

To address these hurdles in the development of a NIWA recycling programme designed to combat environmental Ca decline in Muskoka watersheds, our objectives were to: (i) quantify the total cations and metal concentrations in typical NIWA generated from the combustion of hardwood firewood in central Ontario; (ii) quantify the soluble levels of $\mathrm{Ca}$ and other major cations, anions, and nutrients in NIWA; (iii) compare metal concentrations in NIWA with provincial guidelines and with industrial wood ash; (iv) quantify the actual toxicity of aqueous extracts of NIWA in both water column and sediment deposition scenarios; and $(v)$ estimate the amount of NIWA that might be available in Muskoka, Ontario to launch a residential wood ash recycling programme that could help solve the provincial Ca decline problem.

\section{Materials and methods}

Most central Ontario residents that heat their residences with wood burn hardwood. Azan (2017) reported that $83 \%$ of survey respondents that heat their Muskoka, Ontario homes with wood, burned wood from maple, beech, oak, birch, ash, and cherry trees (in declining order). To address our first four objectives, we obtained hardwood NIWA samples generated over the course of the 2016/2017 winter heating season from nine independent, permanent residents and one wood-fired pizza bakery located in and around Baysville and Bracebridge, Ontario, Canada, that responded to our public call for wood ash. Using a stainless steel riddle (mesh size $2.38 \mathrm{~mm}$ ), we sieved the ash to remove occasional foreign objects (e.g., galvanized nails and staples) and the coarse clinker that is normally generated by incomplete wood combustion. We removed the clinker as our primary focus was on the fly-ash-like component that we assumed would contain the majority of the mineral phases, such as Ca. All subsequent work, analyses for solubility, trace metal concentrations, and potential toxicity once dissolved in soft water medium, was done with these sieved NIWA samples. 


\section{Total and soluble Ca, other cations, and nutrients}

NIWA that might be added to forested watersheds contains $\mathrm{Ca}$ and other nutrients in mineral forms that would likely vary in aqueous solubility in ground or surface waters. To determine levels of total $\mathrm{Ca}$ and other major cations and other nutrients present in hardwood NIWA that would be soluble in the soft waters of the Canadian Shield (objectives 1 and 2), we followed required protocols and sieved $30 \mathrm{~g}$ of each NIWA through a 355 Nitex $\mu \mathrm{m}$ mesh and then divided it into three equal parts for analysis. The 30 resulting NIWA samples were analysed by the Ontario Ministry of Environment, Conservation and Parks (MECP) Laboratory Services Branch, Toronto, Ontario, using hot block digestion and inductively coupled plasma-optical emission spectrophotometry for the total concentrations of the major nutrients, i.e., Ca, potassium $(\mathrm{K})$, magnesium $(\mathrm{Mg})$, sodium $(\mathrm{Na})$, and phosphorus $(\mathrm{P})$.

We assessed the soft water solubility of the NIWA in laboratory at the MECP Dorset Environmental Science Centre (DESC), Dorset, Ontario over $30 \mathrm{~d}$. Our experiment was run in 30, $500 \mathrm{~mL}$ borosilicate glass jars (Mason ${ }^{\circledR}$ jars), into which we dispensed $1 \mathrm{~g}$ of pre-weighed NIWA in $400 \mathrm{~mL}$ of FLAMES (named after the Field Laboratory for the Assessment of Multiple Ecological Stressors located at the DESC) medium, a completely chemically-defined aqueous medium that reflects the major ion chemistry of soft water Canadian Shield lakes with abundant and stable plankton communities (Celis-Salgado et al. 2008). We used three sources of hardwood ash, two collected from local residents and one from the wood-fired pizza bakery $(n=30)$, as using all 10 samples was beyond the resources allocated for the experiment. The Mason jars were shaken once per week to partially simulate disturbance such as rainfall and were partly covered with Parafilm ${ }^{\circledR} \mathrm{M}$ laboratory sealing film to reduce the rate of evaporation. On days $1,6,9,16$, and 30 , we filtered the media from two of the jars from each hardwood source through Supor-200 membrane disc filters $(0.2 \mu \mathrm{m}$ pore size, $47 \mathrm{~mm}$ diameter; PALL Life Sciences, Michigan, USA) to remove wood ash particles. The filtrate was analysed for $\mathrm{Ca}, \mathrm{K}, \mathrm{Mg}$, and $\mathrm{Na}$, total phosphorus (TP), and the anions, chloride $(\mathrm{Cl})$, and sulphate $\left(\mathrm{SO}_{4}\right)$ by the MECP DESC Chemistry Laboratory.

\section{Trace metal analysis}

For our third objective, we compared levels of 11 trace metals with the MECP targets outlined in Ontario Regulation 267/03 of the Nutrient Management Act (Government of Ontario 2002). To determine the trace metal levels, the 30 NIWA samples analysed for total nutrients (method described above) were also analysed by the MECP, Laboratory Services Branch, Toronto, Ontario using (i) cold vapour absorption spectrophotometry (AAS) for mercury ( $\mathrm{Hg}$ ); (ii) hydride-flameless AAS for arsenic (As) and selenium (Se); and (iii) hot block digestion and inductively coupled plasma-optical emission spectrophotometry for all other metals, i.e., cadmium $(\mathrm{Cd})$, chromium $(\mathrm{Cr})$, cobalt $(\mathrm{Co})$, copper $(\mathrm{Cu})$, lead $(\mathrm{Pb})$, molybdenum $(\mathrm{Mo})$, nickel $(\mathrm{Ni})$, and zinc $(\mathrm{Zn})$.

To confirm analytic accuracy we ran the same methodological protocol on a certified reference material that most closely resembled wood ash, and that recorded the largest number of the regulated metals, Trace Metals-Industrial Incinerator Fly Ash obtained from Sigma-Aldrich Canada Co. (CRM012-100G; Lot: LRAB1488). Our measurements agreed with the 95\% predicted interval for the six metals in the reference material where certified levels were provided (i.e., for $\mathrm{Cd}, \mathrm{Cr}, \mathrm{Cu}, \mathrm{Pb}$, $\mathrm{Ni}$, and $\mathrm{Zn}$ ). Given these positive results, we assume we also measured the remaining metals (i.e., As, $\mathrm{Co}, \mathrm{Hg}, \mathrm{Mo}$, and Se) accurately. The methodological protocol used and the MECP laboratory used for the analysis are certified by the Canadian Analytical Laboratory Association (CALA).

\section{Aquatic toxicity bioassays}

Even with the use of best management practices, wood ash from any large-scale NIWA application to forested watersheds could wash into forest streams, wetlands, temporary or permanent ponds, littoral zones, or lakes suffering from Ca decline, causing short-term toxicity while suspended in surface 
mixed layers, and (or) longer-term toxicity after sinking to sediments. Thus, to address objective 4 , we tested both the short-term $(48 \mathrm{~h})$ toxicity of NIWA extracts and the longer-term $(15 \mathrm{~d})$ toxicity of NIWA sedimented slurries to the model bioassay species, Daphnia (Altshuler et al. 2011) in aqueous media.

\section{Daphniid culture}

We assessed the effect of NIWA elutriates on Daphnia using a clonal line of Daphnia pulicaria Forbes, 1893 isolated in 2006 from Red Chalk Lake, District of Muskoka, Ontario. Daphnia pulicaria were maintained in stock cultures in the FLAMES laboratory located at the MECP DESC. Daphnia pulicaria were cultured in FLAMES medium, which was changed once a week, with fresh FLAMES medium and algae (Pseudokirchneriella subcapitata) used as food for the daphniids, and added at a ratio of about $40 \%$ (old) to $60 \%$ (new) medium. Stock populations were housed in Conviron growth chambers (Model E7/2) on a $16: 8 \mathrm{~h} \mathrm{light:dark} \mathrm{cycle,} \mathrm{at} 20^{\circ} \mathrm{C}$.

\section{Short-term toxicity experiment}

Media preparation

NIWA elutriates were prepared from three wood ash sources by adding $150 \mathrm{~g}$ of fine-sieved preweighed ash to $1.5 \mathrm{~L}$ of FLAMES medium (equivalent to a $10 \%$ NIWA solution) and slowly shaking the mixture at $100 \mathrm{rpm}$ for $2 \mathrm{~h}$ and $18 \mathrm{~min}$ on a rotary shaker (Fermentation Design Inc., Allentown, Pennsylvania, USA). This was the time period we estimated (following sedimentation experiments in the lab) that ash would remain in a $5 \mathrm{~m}$ deep, surface mixed layer of a typically sized Muskoka lake. After shaking, we filtered the NIWA elutriate through Supor-200 membrane disc filters ( $0.2 \mu \mathrm{m}$ pore size, $47 \mathrm{~mm}$ diameter; PALL Life Sciences, Michigan, USA) to remove wood ash particles. We then autoclaved the filtrate at $250{ }^{\circ} \mathrm{C}$ for $30 \mathrm{~min}$ to eliminate any risk of biological contamination prior to setting up the bioassays in the FLAMES lab-a clean laboratory.

The experiment had five treatments: the FLAMES medium control, the full strength elutriate, hereafter called the concentrate, and three sequential 10-fold dilutions of the concentrate with FLAMES medium, called DF10, DF100, and DF1000. A $500 \mathrm{~mL}$ subsample of medium from each treatment was analysed for $\mathrm{pH}, \mathrm{Ca}, \mathrm{K}, \mathrm{Mg}, \mathrm{Na}, \mathrm{TP}, \mathrm{Cl}$, and $\mathrm{SO}_{4}$ by the MECP DESC Chemistry Laboratory.

\section{Experimental design}

We used $<24$-h-old $D$. pulicaria neonates, from the third brood of F1 generation individuals born from a set of mothers of identical age, to control for maternal effects (Sakwińska 2004). We exposed $10 D$. pulicaria neonates to each treatment $(n=120)$ for $48 \mathrm{~h}$, with daphniids placed individually in $40 \mathrm{~mL}$ glass vials. We used $48 \mathrm{~h}$ in accordance with test conditions stipulated for conducting Acute Lethality Tests using Daphnia spp. (Environment Canada 1990). No food was added during the test. A small flake of cetyl alcohol $\left(\mathrm{CH}_{3}\left(\mathrm{CH}_{2}\right)_{14} \mathrm{CH}_{2} \mathrm{OH}\right)$ was added to the surface of each vial to prevent neonate entrapment in surface films. Glass vials were covered with Parafilm ${ }^{\circledR} \mathrm{M}$ laboratory sealing film to avoid evaporation and contamination and were positioned randomly within a Percival Incubator (Model GR36L) at $20^{\circ} \mathrm{C}$ on a 16:8 h light:dark cycle. Neonate survival was recorded after 24 and $48 \mathrm{~h}$.

\section{Long-term toxicity experiment}

For our $15 \mathrm{~d}$ sedimented ash bioassay, we added $1 \mathrm{~g}$ of pre-weighed hardwood ash to $250 \mathrm{~mL}$ FLAMES medium in $15500 \mathrm{~mL}$ Mason jars and shook the mixture for $2 \mathrm{~h}$ and $18 \mathrm{~min}$. Once shaken, the supernatant was decanted and fresh FLAMES medium added. We assumed the decanted and discarded supernatant captured the readily soluble NIWA constituents that would be dissolved into the surface mixed layers of a lake, whereas the residual ash reflected what would settle as lake sediments. We allowed the jars' contents to settle for $5 \mathrm{~h}$ prior to the addition of Plexiglas baskets (i.e., Plexiglas cylinders with $130 \mu \mathrm{m}$ mesh glued to the bottom, provided by H. Riessen, SUNY College, Buffalo, 
New York, USA). Daphnia pulicaria neonates were added to each Plexiglas basket in a Mason jar (control and hardwood treatments). Daphniids were fed $0.25 \mathrm{~mL}$ of P. subcapitata three to four times a week. Daily checks were performed for mortality, clutch size, production of offspring and survival for $15 \mathrm{~d}$. All neonates produced during the assay were counted and removed to eliminate competition with the mothers for food.

\section{Estimation of available NIWA}

If there is sufficient quantity, NIWA has the potential to help Ca-stressed watersheds in central Ontario. To estimate the amount of NIWA available in central Ontario (objective 5), we assembled information on: (i) the population size; (ii) the percentage of residents that heat with wood according to Statistics Canada; (iii) the density of wood ash; (iv) the estimated volume of a typical wood ash bucket; and $(v)$ from a questionnaire administered during the 2017 winter heating season (Azan 2017), how many buckets of ash of this volume were typically generated by residents during the heating season, and what fraction of residents would be willing to transport their NIWA to a solid waste transfer station as part of a recycling programme.

\section{Statistical analyses}

We performed all statistical analyses in R 3.2.3 (R Development Core Team 2015). We examined the influence of NIWA ash source (factor with 10 levels) on the concentrations of the 11 trace metals and total nutrients in the dry hardwood ash using one-way analysis of variance (ANOVA). A similar analysis was used to examine the effect of hardwood NIWA on the total number of $D$. pulicaria neonates produced over $15 \mathrm{~d}$ in the long-term bioassay. In cases where normality and assumptions of homoscedasticity were violated for metal concentrations and total nutrients, response variables were log- or $\log _{10}$-transformed to improve normality of residuals and reduce variance differences between ash sources. We used the model that had the lowest Akaike Information Criterion (AIC). The significance of the predictor(s) was determined using ANOVA on the final model. Statistical assumptions of the final model were verified using residual versus fitted plots, scale-location plots, and residuals versus leverage plots.

We used logistic regression with a binomial distribution to analyze the effect of hardwood NIWA on Daphnia survival over $15 \mathrm{~d}$. We also used generalized linear models (GLMs) with a negative binomial distribution to analyze the age of Daphnia to first, second, and third reproduction over $15 \mathrm{~d}$. GLMs were performed using the function glmmADMB v.0.8.3.3 package (Skaug et al. 2016). Model assumptions of the final model were verified using plots of residual versus fitted values and scale-location plots, and estimate of dispersion $(\theta)$. Significance of the predictor in the final GLM model was obtained using log-likelihood ratio tests.

\section{Results}

\section{Total and soluble Ca, other major cations, anions, and other nutrients}

Of the major cations present in wood ash, Ca was dominant with an average of $29.6 \%$ dry weight by mass (DW), followed by $\mathrm{K}$ at $7.9 \% \mathrm{DW}, \mathrm{Mg}$ at $1.7 \% \mathrm{DW}$, and $\mathrm{Na}$ at $0.1 \% \mathrm{DW}$. P concentration was $0.7 \% \mathrm{DW}$. The median DWs for $\mathrm{Ca}, \mathrm{K}, \mathrm{Mg}, \mathrm{Na}$, and $\mathrm{P}$ were $30 \%, 7.6 \%, 1.7 \%, 0.09 \%$, and $0.7 \%$, respectively (Fig. 1).

Major cation concentrations varied among hardwood NIWA samples collected ( $p<0.001 ;$ Fig. 2). Mean Ca concentrations of the hardwood samples ranged from $26.8 \%$ to $31.9 \%$, whereas those for $\mathrm{K}$ ranged from $6.1 \%$ to $10.4 \%$. On average, $\mathrm{Mg}$ concentrations ranged from $1.5 \%$ to $2.4 \%$, whereas those for Na ranged from $0.03 \%$ to $0.15 \%$. Mean P also ranged from $0.5 \%$ to $1.2 \%$. Sample 9 , the 


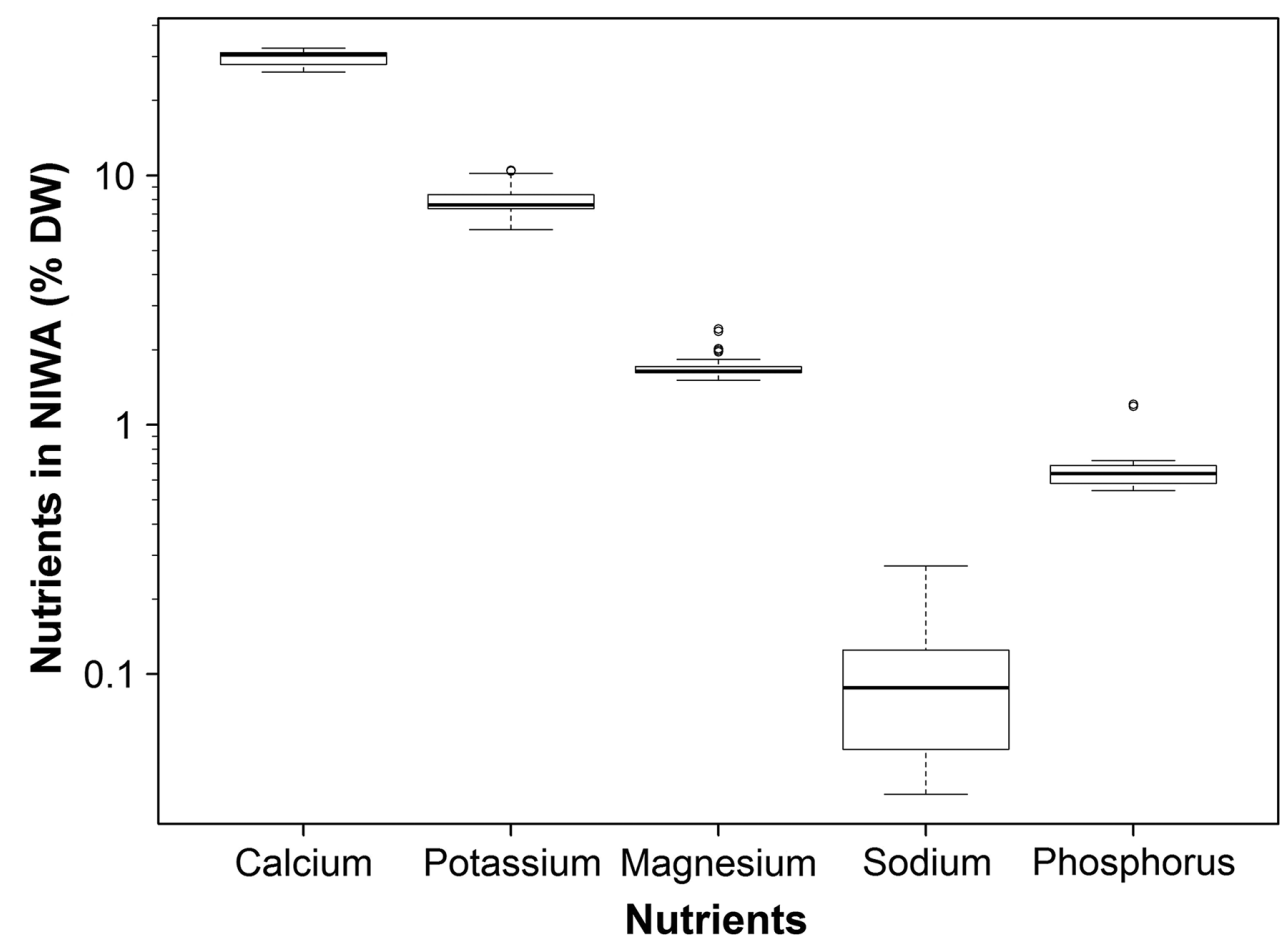

Fig. 1. Percentage of major cations and phosphorus found in hardwood NIWA (\% DW). The bottom and top edges of the boxes represent the first and third quartiles, respectively. The median is represented by the horizontal line. Whiskers encompass data points that lie within 1.5 times the inner quartiles, beyond which are outliers, illustrated as separate points. Note the log scale on the $y$-axis. NIWA, non-industrial wood ash; DW, dry weight by mass.

sample from the wood-fire pizza bakery, had the highest levels of $\mathrm{K}, \mathrm{Mg}, \mathrm{Na}$, and $\mathrm{P}$ compared with the other samples (Fig. 2). However, when we removed Sample 9 from our analysis, there was still a significant effect of ash source on all four cations and $\mathrm{P}(p<0.001)$.

Although Ca was the dominant cation in the NIWA by weight, it was not the most soluble. By the end of the experiment (day 30), we detected, on average, much higher levels of soluble $\mathrm{K}(\sim 9 \% \mathrm{DW})$, when compared with $\mathrm{Mg}(0.7 \% \mathrm{DW}), \mathrm{Ca}(0.4 \% \mathrm{DW}), \mathrm{Na}(0.2 \% \mathrm{DW})$, and the anions $\mathrm{Cl}(0.1 \% \mathrm{DW})$ and $\mathrm{SO}_{4}(1.6 \% \mathrm{DW}$ ). P was the least soluble nutrient on day 30 (mean $0.03 \% \mathrm{DW}$ ) (Fig. 3 ).

\section{Metals}

On average, the majority of the metal concentrations in the 10 hardwood NIWA samples fell below the CM1 standard for unrestricted use. The exceptions were $\mathrm{Cu}$ and $\mathrm{Zn}$ which had mean concentrations just above the CM1 target, but still well below the CM2 levels for restricted use (Table 1 ). Of the 11 metals analysed, $\mathrm{Cd}, \mathrm{Cu}, \mathrm{Mo}$, and $\mathrm{Zn}$ had higher concentrations for the mean $+2 \times \mathrm{SD}$ (a level we might expect to exceed in $2.5 \%$ of the samples) when compared with the CM1 target (Table 1). Nonetheless, these extreme samples still had levels 140\%, 169\%, 176\%, and 139\%, respectively, lower than the CM2 standard (Table 1). Similarly, $\mathrm{Cd}, \mathrm{Cu}$, and $\mathrm{Zn}$ exhibited higher levels for the upper confidence limit when compared with the CM1 target, but were still below their respective CM2 standard. None of our individual hardwood NIWA sample means fell above the CM2 targets listed for the 11 trace metals analysed.

Trace metal concentrations in hardwood NIWA did, however, vary among ash sources. We detected a significant effect of ash source on 9 of the 11 trace metals analysed (i.e., $\mathrm{As}, \mathrm{Cd}, \mathrm{Cr}, \mathrm{Co}, \mathrm{Cu}, \mathrm{Pb}, \mathrm{Mo}$, 

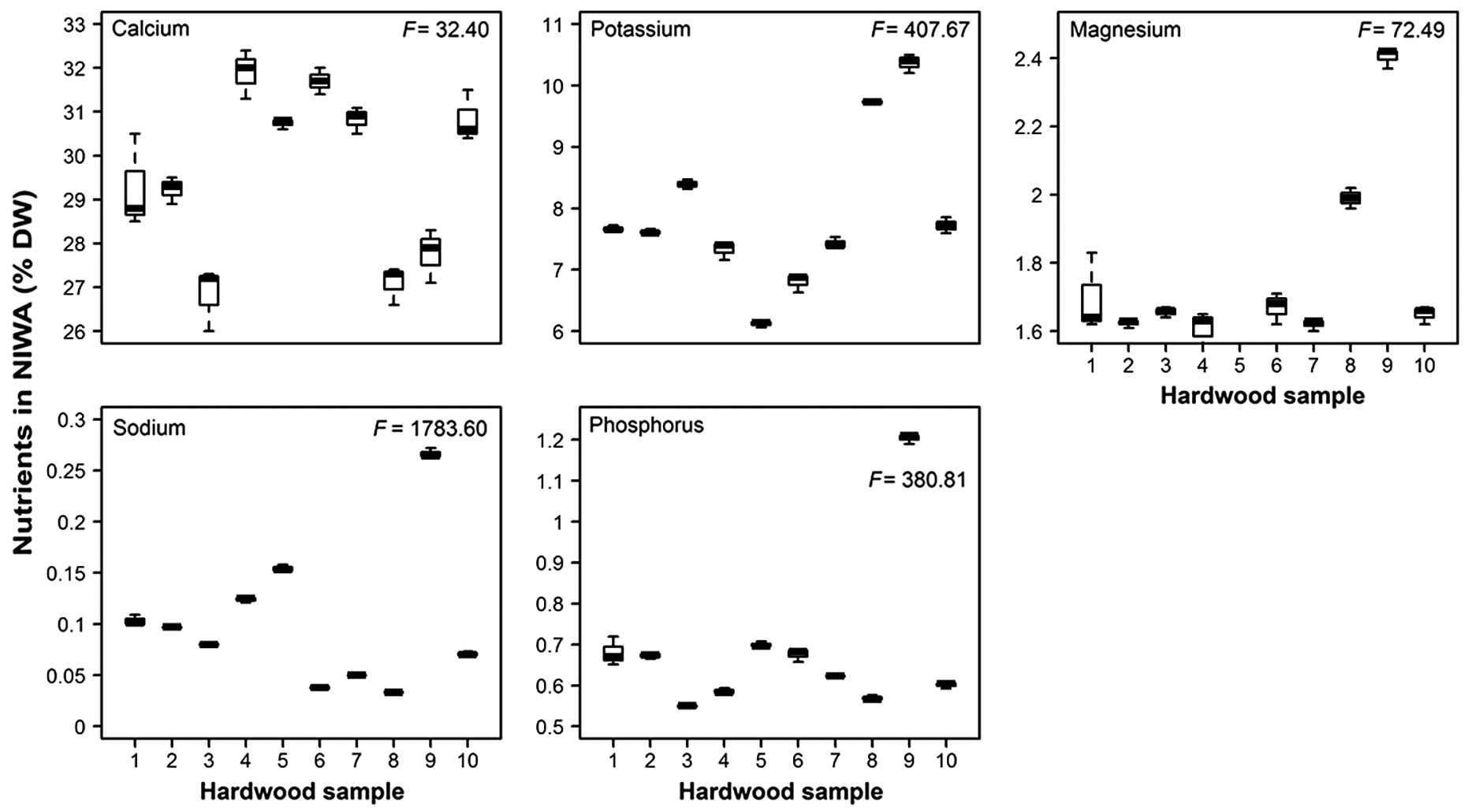

Fig. 2. Percentage of nutrients (\%) of the major cations and phosphorus observed in individual hardwood NIWA samples. The bottom and top edges of the boxes represent the first and third quartiles, respectively. The median is represented by the horizontal line. Whiskers encompass data points that lie within 1.5 times the inner quartiles, beyond which are outliers, illustrated as separate points. Note the different scales on the $y$-axes. $F$ values for one way ANOVAs are presented in each panel ( $\mathrm{df}$ in each case 9,20 and $p<0.001$ ). NIWA, non-industrial wood ash; ANOVA, analysis of variance.

$\mathrm{Ni}$, and $\mathrm{Zn})(p<0.001 ; \mathrm{Fig} .4)$. The exceptions were $\mathrm{Hg}$ and $\mathrm{Se}(p=0.471)$ that had the same concentrations $(0.01 \mathrm{mg} / \mathrm{kg}$ and $0.2 \mathrm{mg} / \mathrm{kg}$ DW, respectively) for all ash sources analysed, and represented the detection limits for these metals. Metal concentrations for As ranged from $0.4 \mathrm{mg} / \mathrm{kg} \mathrm{DW}$ to $1.6 \mathrm{mg} / \mathrm{kg} \mathrm{DW}$; Cd, $0.3 \mathrm{mg} / \mathrm{kg} \mathrm{DW}$ to $5.3 \mathrm{mg} / \mathrm{kg} \mathrm{DW}$; Cr, $0.6 \mathrm{mg} / \mathrm{kg} \mathrm{DW}$ to $6.7 \mathrm{mg} / \mathrm{kg} \mathrm{DW}$; Co, $0.5 \mathrm{mg} / \mathrm{kg}$ DW to $2.7 \mathrm{mg} / \mathrm{kg} \mathrm{DW}$; $\mathrm{Cu}, 76.8 \mathrm{mg} / \mathrm{kg}$ DW to $137.3 \mathrm{mg} / \mathrm{kg} \mathrm{DW} ; \mathrm{Pb}, 1.5 \mathrm{mg} / \mathrm{kg}$ DW to $8.2 \mathrm{mg} / \mathrm{kg}$ DW; Mo, $1.5 \mathrm{mg} / \mathrm{kg}$ DW to $5 \mathrm{mg} / \mathrm{kg}$ DW; Ni, $0.3 \mathrm{mg} / \mathrm{kg}$ DW to $6 \mathrm{mg} / \mathrm{kg} \mathrm{DW}$; and Zn, $273.3 \mathrm{mg} / \mathrm{kg}$ DW to $667.3 \mathrm{mg} / \mathrm{kg}$ DW.

\section{Short-term toxicity}

Hardwood NIWA treatments influenced $D$. pulicaria neonate survival over $48 \mathrm{~h}$. By the end of the experiment, all daphniid neonates died in both the concentrate and DF10 treatments compared with the control. As the dilution factor in our treatments increased, so did the survival rate of the neonates. After $48 \mathrm{~h}$, all daphniid neonates were alive in both the DF100 and DF1000 treatments and the control.

\section{Long-term toxicity}

\section{Survival}

Sedimented NIWA did not have a significant effect on D. pulicaria survival over $15 \mathrm{~d}(p=0.57)$. In the initial stages of the experiment, the proportion of daphniid neonates alive in jars with hardwood 

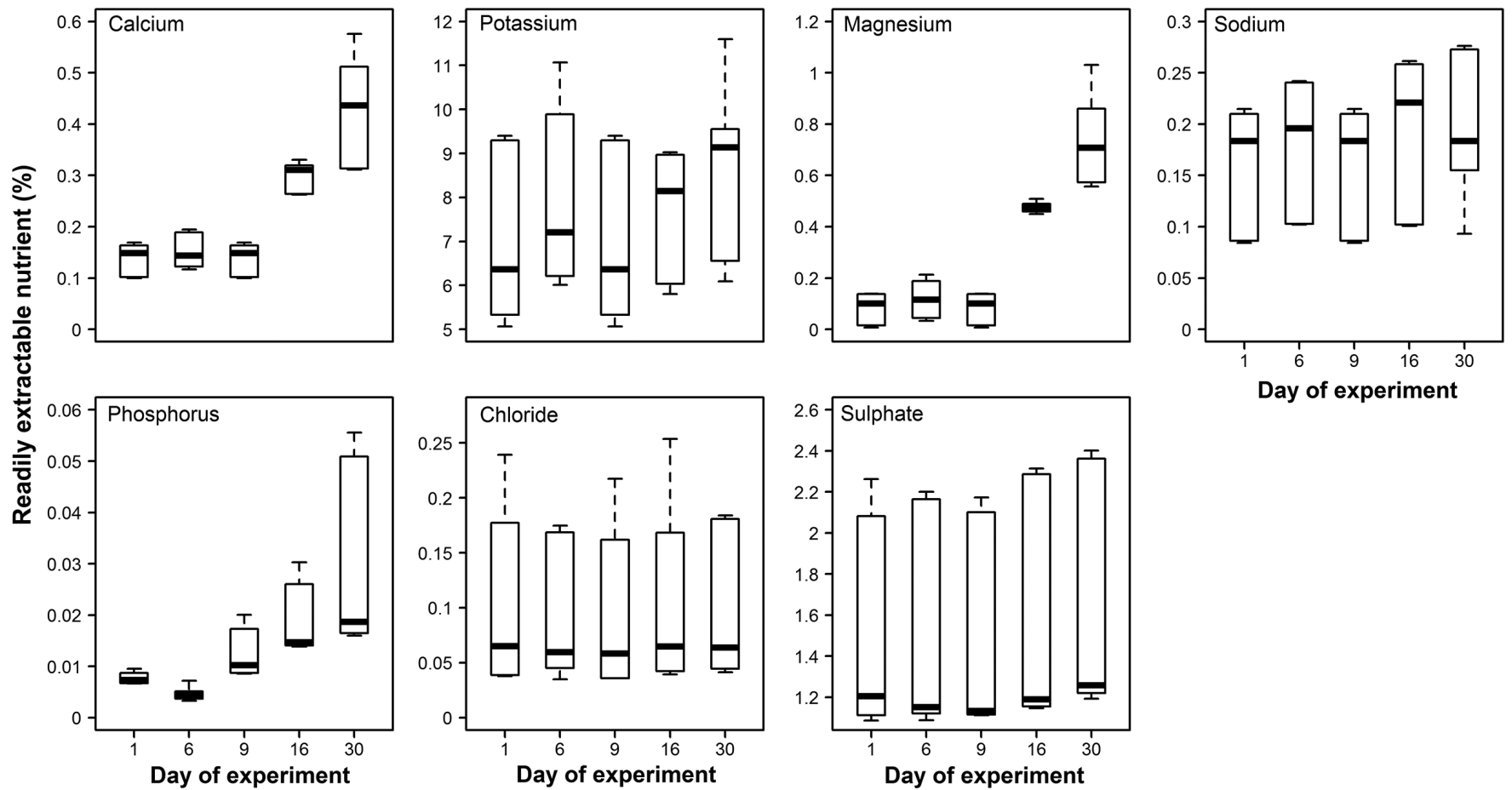

Fig. 3. Readily extractable nutrients (\%) of the major cations, anions, and phosphorus. The bottom and top edges of the boxes represent the first and third quartiles, respectively. The median is represented by the horizontal line. Whiskers encompass data points that lie within 1.5 times the inner quartiles, beyond which are outliers, illustrated as separate points. Note the different scales on the $y$-axes.

Table 1. Ontario government standards for unrestricted (CM1) and restricted (CM2) use of wood ash as a non-agricultural source material (from Hannam et al. 2016), compared with average metal concentrations of 10 hardwood NIWA samples and their standard error, the upper $95 \%$ confidence limit of the mean, and the mean plus two times the standard deviation.

\begin{tabular}{|c|c|c|c|c|c|c|}
\hline \multirow[b]{2}{*}{ Element } & \multicolumn{2}{|c|}{$\begin{array}{c}\text { Non-aqueous } \\
\text { material (mg/kg DW) } \\
\end{array}$} & \multirow{2}{*}{$\begin{array}{c}\text { Observed } \\
\bar{X}(n=10)\end{array}$} & \multirow{2}{*}{$\begin{array}{c}\text { SE of } \\
\text { observed } \bar{X}\end{array}$} & \multirow{2}{*}{$\begin{array}{c}\text { Upper } \\
\text { confidence limit }\end{array}$} & \multirow{2}{*}{$\begin{array}{r}\text { Mean + } \\
2 \times \text { SD }\end{array}$} \\
\hline & CM1 & CM2 & & & & \\
\hline Arsenic & 13 & 170 & 0.61 & 0.14 & 0.93 & 1.51 \\
\hline Cadmium & 3 & 34 & 2.02 & 0.63 & 3.45 & 6.02 \\
\hline Chromium & 210 & 2800 & 2.92 & 0.68 & 4.45 & 7.20 \\
\hline Cobalt & 34 & 340 & 1.11 & 0.19 & 1.54 & 2.31 \\
\hline Copper & 100 & 1700 & 100.49 & 6.41 & 115.00 & 141.05 \\
\hline Lead & 150 & 1100 & 3.05 & 0.75 & 4.74 & 7.77 \\
\hline Mercury & 0.8 & 11 & 0.01 & 0 & 0.01 & 0.01 \\
\hline Molybdenum & 5 & 94 & 2.65 & 0.52 & 3.83 & 5.95 \\
\hline Nickel & 62 & 420 & 4.18 & 0.80 & 5.98 & 9.23 \\
\hline Selenium & 2 & 34 & 0.21 & 0.01 & 0.22 & 0.25 \\
\hline Zinc & 500 & 4200 & 500.6 & 39.66 & 590.32 & 751.45 \\
\hline
\end{tabular}

Note: Numbers in bold indicate metal concentrations that fell above CM1 but all were well below the CM2 targets. NIWA, non-industrial wood ash; DW, dry weight by mass; SE, standard error, SD, standard deviation. 

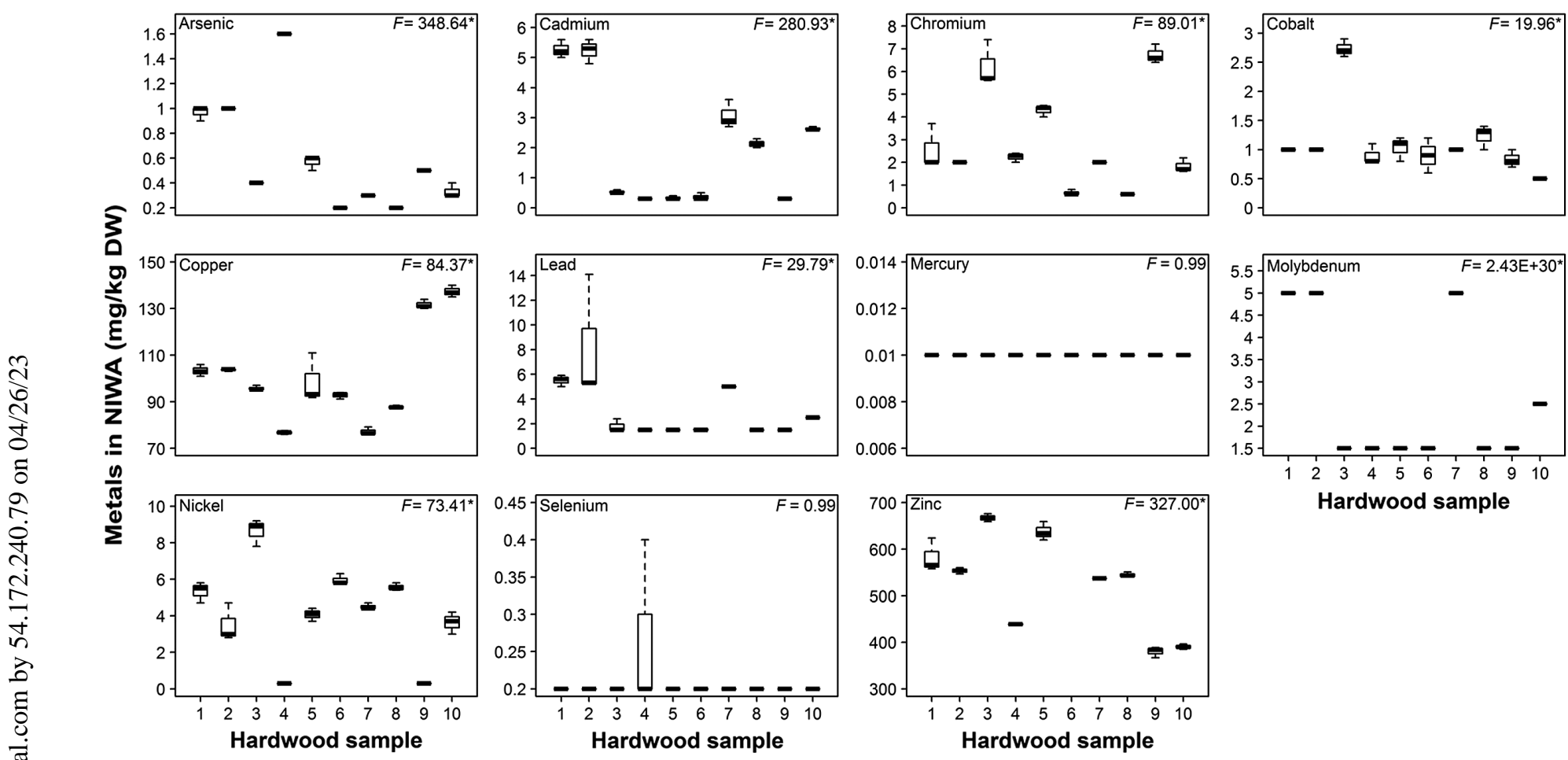

4. Concentrations of 11 trace metals ( $\mathrm{mg} / \mathrm{kg} \mathrm{DW}$ ) observed in individual hardwood NIWA samples. Bottom and top edges of boxes represent the first an third quartiles, respectively. The median is represented by the horizontal line. Whiskers encompass data points that lie within 1.5 times the inner quartiles, beyond which are outliers, illustrated as separate points. Note the different scales on the $y$-axes. $F$ values for one way ANOVAs are presented in each panel (df in each case 9,20). p-values $<0.05$ were considered significant and are indicated by an asterisk in each panel. DW, dry weight by mass; NIWA, non-industrial wood ash; ANOVA, analysis of variance.

NIWA was 7\% higher than in the control. This trend disappeared by the end of the experiment, as the proportion of neonates alive in jars containing hardwood NIWA was slightly, although not significantly, lower than those for the control (0.8 versus 0.87 ) (Fig. 5).

\section{Number of neonates produced}

Sedimented NIWA did not have a significant effect on the total number of Daphnia neonates produced over $15 \mathrm{~d}\left(F_{(1,26)}=0.0001, p=0.99\right)(F i g .6)$. By the end of the experiment, on average, 17 Daphnia neonates were observed per mature individual in jars containing both sedimented NIWA and the control.

\section{Age at maturation}

Like neonate production, sedimented NIWA did not have a significant effect on age of Daphnia at first reproduction ( $\log$ ratio test, deviance $=-0.09, \theta=0.15, p=0.76$ ). We also detected no significant effect on either second ( $\log$ ratio test, deviance $=-0.74, \theta=0.54, p=0.39$ ) or third (log ratio test, deviance $=-0.89, \theta=0.62, p=0.35)$ reproduction. On average, Daphnia mothers exposed to sedimented NIWA produced their first clutch at least $1 \mathrm{~d}$ earlier than the control ( 8 versus $9 \mathrm{~d}$ old). This trend was not evident for both second and third reproduction where, on average, Daphnia mothers exposed to sedimented ash produced their clutches $1 \mathrm{~d}$ later when compared with the control (2nd: 11 versus $10 \mathrm{~d}$ old; 3 rd: 12 versus $11 \mathrm{~d}$ old) (Fig. 7). 


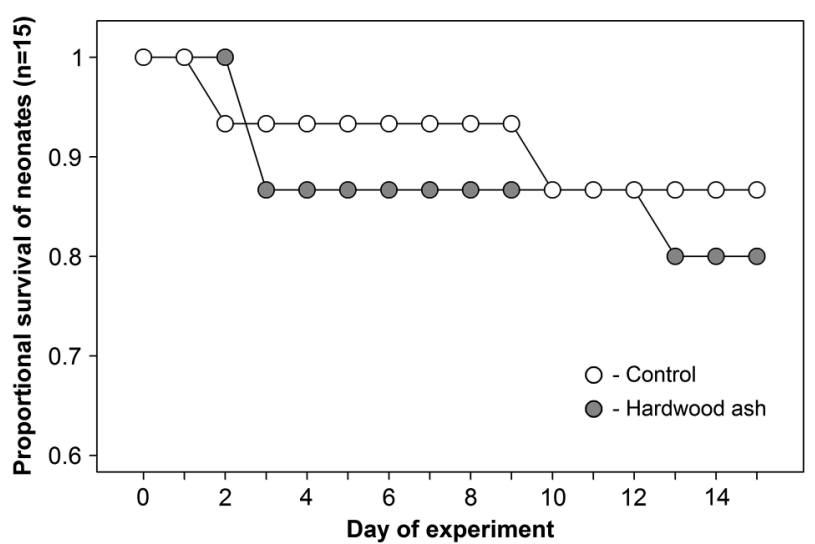

Fig. 5. Proportional survival of Daphnia neonates exposed to hardwood NIWA compared with the control over 15 d. NIWA, non-industrial wood ash.

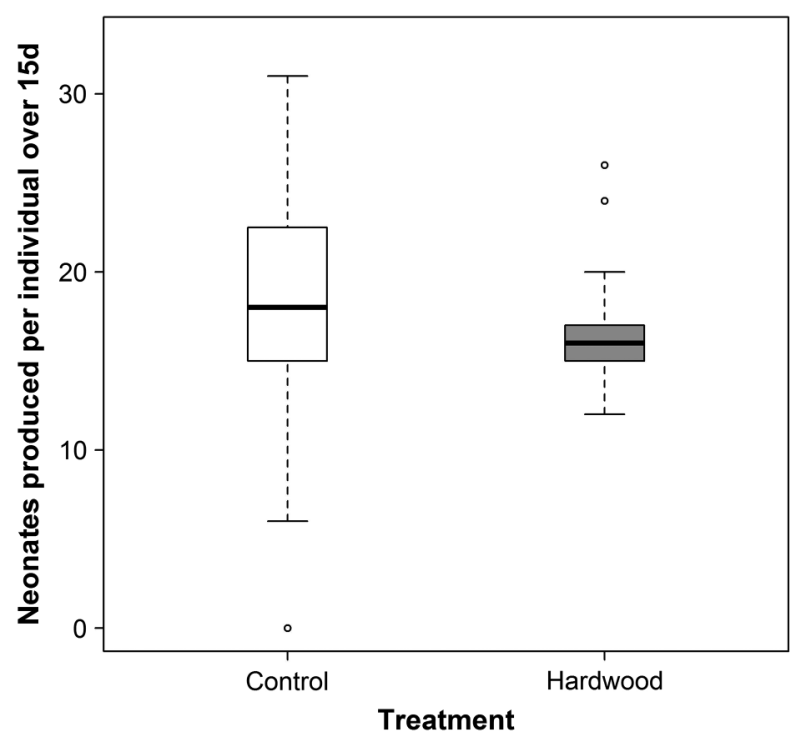

Fig. 6. Total number of Daphnia neonates produced per individual in hardwood NIWA compared with the control. The bottom and top edges of the boxes represent the first and third quartiles, respectively. The median is represented by the horizontal line. Whiskers encompass data points that lie within 1.5 times the inner quartiles, beyond which are outliers, illustrated as separate points. NIWA, non-industrial wood ash.

\section{Estimate of the amount of NIWA available in central Ontario}

We estimated that residents of Muskoka that heat with wood could provide about $235000 \mathrm{~kg}$ (235 tonnes) of NIWA per year. There are currently 60599 permanent residents in Muskoka (The District Municipality of Muskoka 2015-2016 census) of which 3\% heat with wood (Statistics Canada n.d.). If the majority of these wood burners produce 20 buckets of ash per heating season (Azan 2017), they would produce 36359 buckets of NIWA. Assuming a typical ash pail holds $17.7 \mathrm{~L}$, residents in Muskoka would generate about $643561 \mathrm{~L}$ of ash. As the average density of wood ash is $548 \mathrm{~kg} / \mathrm{m}^{3}$ (Naik et al. 2001)-it varies with wood species-about $352672 \mathrm{~kg}$ ( $\sim 353$ tonnes) of ash would be produced. Azan (2017) reported that two-thirds of 


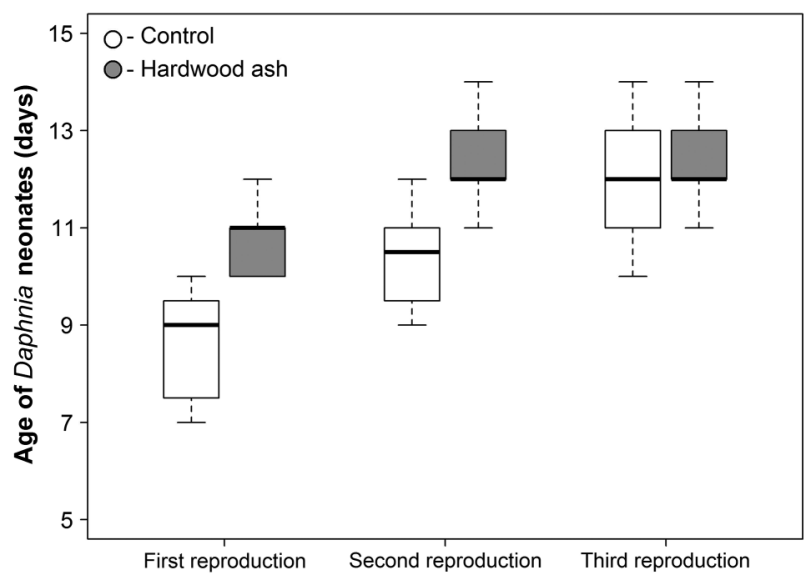

Fig. 7. Maturation rates of Daphnia exposed to hardwood NIWA compared with the control. The bottom and top edges of the boxes represent the first and third quartiles, respectively. The median is represented by the horizontal line. Whiskers encompass data points that lie within 1.5 times the inner quartiles, beyond which are outliers, illustrated as separate points. NIWA, non-industrial wood ash.

residents were willing to transport their NIWA to a landfill or transfer station. Thus, they would deliver about $235000 \mathrm{~kg}$ (235 tonnes) of NIWA. There would, of course, be other small NIWA sources (e.g., wood-fired pizza bakeries) we have not included, plus a few larger industrial sources.

\section{Discussion}

Our study was designed to determine if non-industrial, mainly residential wood ash (NIWA) has the potential to be used as a forest soil amendment in central Ontario and be part of the solution to the widespread environmental Ca decline problem in central Ontario lakes and forests (Watmough and Dillon 2003a, 2003b; Jeziorski et al. 2008). To date, this NIWA source has neither been considered as a large-scale forest soil additive, nor as an aid to reverse widespread Ca decline in lakes, likely because of its unknown chemistry and distributed production. We do not think the latter reason should impede its consideration. After all, distributed production has not stopped any other residential recycling initiative.

To examine the question of whether NIWA could be part of the solution to Muskoka's environmental Ca decline, we must: ( $i$ ) document the concentration and solubility of $\mathrm{Ca}$ in the ash as part of the sitespecific calculation of required application rates; (ii) compare levels of potentially toxic metals with regulated targets; (iii) if possible, quantify the actual toxicity of the wood ash to terrestrial and aquatic model species; (iv) quantify levels of any non-metallic ash components (organics and $\mathrm{P}$ ) that might also pose environmental issues; $(v)$ document quantities of NIWA that are produced annually in the region, and would likely be made available for the recycling programme; ( $v i)$ test the dosage calculations and ecotoxicological implications of NIWA issues in pilot studies, perhaps using an adaptive management philosophy; and (vii) resolve any major policy, logistical, economic, and stakeholder questions and impediments related to ash collection and post-collection treatment, e.g., pelletization, storage, delivery, distribution, and application. We have largely focused on the first five of these requirements in this paper. We recognize that the last two issues, particularly the last one, are major, so we do consider them briefly in the terminus of our Discussion.

However, to eliminate any confusion in the Discussion, we should briefly consider the goals of such a residential wood ash recycling programme. We suggest its central goals should be to: $(i)$ increase 
citizen participation in environmental stewardship; (ii) increase the diversion of waste from landfill sites; (iii) reverse decades of Ca loss from watershed soils, thus increasing carbon capture and health of forests in eastern Canada; and (iv) indirectly, solve the widespread Ca loss problem in lakes by restoring soil base cation pools.

Our NIWA samples averaged 30\% Ca and could replace missing Ca levels in forest soils. Such high levels of $\mathrm{Ca}$ are in agreement with those reported for wood-derived boiler ash: 3.6\%-96.6\% (as reviewed by Vance 1996), 13.2\%-27\% (Naylor and Schmidt 1986), 11.9\%-28.4\% (Steenari and Lindqvist 1997), and 9.2\%-24.79\% (AshNet 2018). Our results confirm Ca levels observed in ash from a home wood stove: $28.1 \%-32.1 \%$ (Naylor and Schmidt 1986). Although our focus was on hardwood NIWA, we had an additional source of ash from a resident that burned exclusively wood pellets made from northern pine and spruce trees. This sample had a higher Ca concentration of 37\% (Azan 2018), but we would need additional samples to confirm that wood pellet stoves routinely produce ash with such high Ca levels.

Although our NIWA samples contained high total levels of Ca, it was not particularly soluble. Ca was released into aqueous media slowly from our hardwood NIWA, especially in the first $9 \mathrm{~d}$ of exposure (Fig. 3). However, by day 30 of the solubility experiment, $0.4 \%$ of the total Ca was in solution, reaching an average of $\sim 11 \mathrm{mg} / \mathrm{L}$ of $\mathrm{Ca}$, still lower than the $15 \mathrm{mg} / \mathrm{L}$ we might have expected from the known solubility of $\mathrm{CaCO}_{3}$, the primary Ca compound found in wood ash (Steenari and Lindqvist 1997; Serafimova et al. 2011). Such gradual solubility suggests that hardwood NIWA could be useful in the long term as a slow-release source of Ca for Muskoka forests, and potentially for low Ca lakes should wood ash be leached to them.

Our results suggest that heavy metal concentrations in NIWA should not prevent its use as a forest soil additive. None of the samples exceeded the CM2 standard, which would prevent use. Indeed, the majority of trace metal concentrations in the NIWA fell below the regulated levels for CM1, the target for unrestricted use (Table 1 ). The exceptions were $\mathrm{Cu}$ and $\mathrm{Zn}$, whose averages were just above the CM1 targets but well below the CM2 standard. The peak value we might expect to see in only $2.5 \%$ of NIWA samples also exceeded the CM1 target for $\mathrm{Cu}$ and $\mathrm{Zn}$, as expected, given their means, but also for $\mathrm{Cd}$. Such elevated levels of $\mathrm{Cu}$ and $\mathrm{Zn}$, and on occasion $\mathrm{Cd}$, likely reflect the unusually high metal deposition rates that occurred over the past 50 years or so (Pratte et al. 2013) that are now reflected in forest soils (Landre et al. 2010; Watmough 2010; Doucet et al. 2012) and lake sediments (Couillard et al. 2008; Landre et al. 2010). Any wood being burned now likely came from the same time period. As atmospheric metal deposition rates peaked several decades ago and are in decline, metal concentrations in NIWA will likely be lower in the future. Although it is unlikely that these rare individual samples would render bulk NIWA unusable, further metal analyses would certainly be required on bulk ash mixtures, as they are recycled for compost.

It is noteworthy that mean metal concentrations in our NIWA tended to be much lower than the mean and minimum values for industrial sources of wood ash (Table 2), with the exception of $\mathrm{Cu}$ and $\mathrm{Zn}$. These results suggest that NIWA would be no more of a toxic threat, if any, than many industrial sources of ash as an additive to forest soils in central Ontario. Hence, we do not think that the use of hardwood NIWA would result in metal toxicity in the receiving soil.

We provide the first direct assessment of the potential short- and longer-term toxicity of aqueous extracts of NIWA to Daphnia. Although we did detect acute toxicity in concentrates, this completely disappeared with modest dilution, and we detected no toxicity of sedimented NIWA on Daphnia survival, maturation, or brood production. Still, the high mortality in the concentrate and DF10 treatments must be explained. Beyond the strength of the concentrate itself (a 10\% ash solution), 
Table 2. Elemental composition of fly ash from nine industrial sources compared with NIWA analysed in this study.

\begin{tabular}{|c|c|c|c|c|}
\hline \multirow[b]{2}{*}{ Metals } & \multicolumn{2}{|c|}{ NIWA fly ash ${ }^{a}(\mathrm{mg} / \mathrm{kg})$} & \multicolumn{2}{|c|}{ Industrial fly ash $^{b}(\mathrm{mg} / \mathrm{kg})$} \\
\hline & Mean & Range & Mean & Range \\
\hline Arsenic & 0.61 & $0.2-1.6$ & 13.5 & $3.6-27.9$ \\
\hline Cadmium & 2.02 & $0.3-5.6$ & 8.9 & $2.3-17.8$ \\
\hline Chromium & 2.92 & $0.6-7.4$ & 35.2 & $15.0-67.9$ \\
\hline Cobalt & 1.11 & $0.5-2.9$ & 11.5 & $4.8-20.1$ \\
\hline Copper & 100.49 & $76.0-140.0$ & 83.5 & $35.0-144.6$ \\
\hline Lead & 3.05 & $1.5-14.1$ & 20.3 & $3.3-61.3$ \\
\hline Mercury & 0.01 & - & NA & - \\
\hline Molybdenum & 2.65 & $1.5-5.0$ & 7.9 & $2.9-36.9$ \\
\hline Nickel & 4.18 & $0.3-9.2$ & 41.5 & $10.4-184.4$ \\
\hline Selenium & 0.21 & $0.2-0.4$ & 9.6 & $1.5-20.0$ \\
\hline Zinc & 500.6 & $264-676$ & 1178.9 & $388.9-2661.5$ \\
\hline
\end{tabular}

Note: Observed means and ranges from all studies presented are reported. NIWA, non-industrial wood ash; NA, data not available.

${ }^{a}$ Our study.

${ }^{b}$ AshNet (2018) (biomass boilers at pulp and paper mills and bioenergy co-generation facilities).

we hypothesized this mortality had one of two logical sources: (i) the high $\mathrm{pH}$ of the solutions, or (ii) the concentration of elements present in the NIWA, including both metals and cations, other than $\mathrm{Ca}$. The $\mathrm{pH}$ of the concentrates ranged from 10.65 to 12.49 . To determine if the high $\mathrm{pH}$ of the concentrate and DF10 treatments explained the observed mortality rates, we repeated the $48 \mathrm{~h}$ experiment after first lowering the $\mathrm{pH}$ to 8 , a $\mathrm{pH}$ typical of hard water lakes. As in the initial $48 \mathrm{~h}$ experiment without the $\mathrm{pH}$ adjustments, we detected $100 \%$ mortality rates in the concentrate and DF10 treatments, but excellent survival in the DF100 and DF1000 treatments (Table S1). We concluded that high $\mathrm{pH}$ was not the cause of the mortality observed in Daphnia neonates.

Our alternate hypothesis was that some other element (or elements) present in the NIWA extract was responsible for the observed mortality in the concentrate and DF10 treatments. We do not think that $\mathrm{Cu}$ or $\mathrm{Zn}$ were the responsible toxicants, because at the high $\mathrm{pH}$ of the medium, very little, if any, $\mathrm{Cu}$ or Zn would have been soluble (Dortwegt and Maughan 2001; Jarvis et al. 2012). The most logical possibility was K, which was very soluble in our NIWA (Fig. 3). K levels in the concentrate and DF10 treatments ranged, respectively, from 2699 to $7871 \mathrm{mg} / \mathrm{L}$, and 296 to $449 \mathrm{mg} / \mathrm{L}$, much higher than the acute LC50 of $93 \mathrm{mg} / \mathrm{L}$ measured by Biesinger and Christensen (1972). To check K toxicity to our daphniid clone in our soft water medium, we ran a $48 \mathrm{~h}$ bioassay using potassium chloride $(\mathrm{KCl})$ at $\mathrm{K}$ concentrations of $50,100,150,200$, and $250 \mathrm{mg} / \mathrm{L}$. We observed $100 \%$ survival in the first three concentrations $(50,100$, and $150 \mathrm{mg} / \mathrm{L})$, then $80 \%$ and $0 \%$ survival in the final two concentrations, i.e., at 200 and $250 \mathrm{mg} / \mathrm{L}$ of $\mathrm{K}$, respectively (Table S2). Interpolation of the survival (\%) versus K concentration data provided an acute LC50 for K for our daphniid clone of between 200 and $250 \mathrm{mg} / \mathrm{L}$, slightly higher than Biesinger and Christensen's (1972) value. This amount of variation in LC50s for metals is well known in inter-laboratory studies using Daphnia (Baird et al. 1990). These results strongly support the hypothesis that enough $\mathrm{K}$ was solubilized from the NIWA to account for the mortalities observed in the concentrate and DF10 treatments in the acute bioassays. Daphnia neonates exposed to high levels 
of K concentrations (ranging from 195.5 to $1560 \mathrm{mg} / \mathrm{L}$ ) would experience a depressed heart rate, and eventually death (Baylor 1942). However, we do not expect such K toxicity from NIWA applications in nature, given ash dilution over time and distance. All required elements can exist at sub-optimal, optimal, and toxic levels, and it was our extreme concentrate (a 10\% ash solution) that produced toxic levels in our assays. Still, as a precaution, $\mathrm{K}$ levels in ground and surface waters should be tracked shortly after NIWA additions, especially following precipitation events. We do know that the NIWA contains a lot of soluble K (Fig. 3). Further, if spread, the NIWA should be dispersed widely, not left in concentrated piles, which might produce localized toxic levels of $\mathrm{K}$ after rain storms.

In addition to $\mathrm{Ca}$ and $\mathrm{K}$, concentrations of other nutrients varied across the 10 hardwood NIWA samples. This result was expected as the chemical composition of wood ash can vary among tree species used as fuel, with the parts of tree in the fuel (e.g., bark, twigs, wood, and leaves), with the chemistry of the soil that supported the trees, with combustion temperature and type, and with storage of fuel wood (as reviewed by Vance 1996; Demeyer et al. 2001; Pitman 2006). In central Ontario, local residents and the wood-fired pizza bakery burn the main stem or trunk of trees, bark, or branches (in descending order) of hardwood tree species (e.g., maple, oak, and beech) as a heating source (Azan 2017), which might account for the variation in nutrients observed across the 10 hardwood samples collected. This is consistent with observations by Pitman (2006), who also highlighted the variability in nutrient concentrations in ash that resulted from burning different tree species and tree parts. Sample 9 came from a wood-fired pizza bakery, and its higher levels for $\mathrm{K}, \mathrm{Mg}, \mathrm{Na}$, and $\mathrm{P}$ could be due to the dosing of pizza bases with flour as they were placed in the oven. It is worth noting that flour has high concentrations of $\mathrm{K}(4 \%), \mathrm{P}(13 \%)$, and $\mathrm{Mg}(7 \%)$ compared with the bole wood of trees.

Wood ash can have high P concentrations, and we could not recommend the large-scale addition of NIWA to the forest as a treatment for $\mathrm{Ca}$ decline if it would lead to the eutrophication of downstream waters. However, we feel this risk is low. P was the least soluble of the elements, at only $0.02 \%$ after $30 \mathrm{~d}$ for ash obtained from residences, and $0.05 \%$ for ash from the pizza bakery (Sample 9). From the dry ash analysis, we noted that Sample 9 contained $1.2 \%$ of $\mathrm{P}$, about twice the $0.6 \% \mathrm{P}$ average from the other nine sources of NIWA, all of which were residential (Fig. 2). To explore the possibility that $\mathrm{P}$ in NIWA might pose a risk of eutrophication, we estimated the amount of readily available $\mathrm{P}$ that would be supplied to a watershed receiving 4 tonnes of NIWA/ha of watershed-a suggested minimum application rate that could be used to help solve the Ca decline problem in Muskoka (C. Reid, personal communication, 2017). At 4 tonnes $/$ ha, $~ 800 \mathrm{~g}(0.8 \mathrm{~kg})$ of $\mathrm{P} / \mathrm{ha}$ (Appendix 2: Azan 2018) - would be readily available to watershed soils. This value is roughly equivalent to the natural load of $\mathrm{P}$ from rain and snow of $750 \mathrm{~g}(0.75 \mathrm{~kg}) / \mathrm{ha}$, recorded annually in Muskoka (Nicholls and Cox 1978), and is 16 times and three times more, respectively, than is normally released annually from forested areas in Muskoka (50 g/ha: Dillon and Rigler 1975), and from the average stream exports of six soft water lakes in south-central Ontario ( $231 \mathrm{~g} / \mathrm{ha}$; Eimers et al. 2018). As a precaution, changes in TP concentrations in ground and surface waters should be tracked post-addition of NIWA in watershed soils.

We do not think enough NIWA is generated in Muskoka to solve the Ca decline problem in local forests and lakes, given its widespread nature, but enough ash is generated in Ontario. Muskoka residents generate about $235000 \mathrm{~kg}$ (235 tonnes) of NIWA per heating season. If the estimated net loss of Ca from the soil exchangeable pool is $7.14 \mathrm{~kg} / \mathrm{ha}$ per year (Watmough and Dillon 2003a), then the amount of Ca lost over the past 50 years of acid deposition is roughly $360 \mathrm{~kg} / \mathrm{ha}$ or 0.36 tonnes/ha. If all the $\mathrm{Ca}$ in wood ash was soluble, this would require about a tonne of wood ash/ha. Assuming 4 tonnes/ha would be appropriate, Muskoka's 235 tonnes of annual ash would treat only 58 ha, enough for a large plot-scale study, but not enough to solve the problem given its widespread nature 
(Reid and Watmough 2016). However, about 18000 tonnes of residential wood ash are generated in Ontario annually (Azan 2017). In principle, this is enough to treat 4500 ha of Muskoka forests per year that certainly begins to address the scope of the problem over a decade or two. This suggests a province-wide NIWA recycling programme is worth considering as an option to solve the Ca decline problem in central Ontario. Of course, the inclusion of industrial sources of wood ash could shorten the time required to solve the problem.

Approved wood ash dosage rates have not been set for forest soils across Canada, and most provinces determine recommended doses based on the liming requirement of the soil and (or) on the trace metal levels in the ash and receiving soil (as reviewed by Hannam et al. 2016). In Europe, approved doses range from 0.5 to 7.5 tonnes/ha, some of which are based on the quantity of $\mathrm{Cd}$ or $\mathrm{P}$ in the soil, the site (e.g., mixed peatland or upland forests), and soil type (e.g., nutrient poor sandy soils) (as reviewed by Hannam et al. 2016). Field trials currently underway by participants in Canada's national wood ash research network, AshNet (nrcan.gc.ca/forests/researchcentres/glfc/ashnet/20279) - whose primary focus is forest productivity - are using similar dosage rates for industrial ash as used in Europe (ranging from 0.5 to 20 tonnes/ha; Hannam et al. 2018). However, there is currently no understanding of what wood ash application rates to forested watersheds are needed to raise Ca concentrations in downstream waters to $>1.5 \mathrm{mg} \mathrm{Ca} / \mathrm{L}-\mathrm{a}$ biological threshold above which Daphnia reproduction and survival increases (Ashforth and Yan 2008). As we expect Ca concentrations in many central Ontario lakes to fall to $1 \mathrm{mg} / \mathrm{L}$ or less (Reid and Watmough 2016), there is clearly work to be done.

Although we have shown that, like industrial wood ash, NIWA can be used as a forest soil additive and, in consequence, benefit Muskoka forests and lakes, there are several barriers that prevent its wide-scale use as a forest soil additive in Canada. In their recent review, Hannam et al. (2018) indicated that regulatory approval, the variability of wood ash chemistry, and a lack of knowledge of the effects of wood ash on forested sites are just some of the issues to overcome. The variability of NIWA is unlikely to be an issue, as metal concentrations are often lower than industrial sources and ash from treated or salt-laden wood are unlikely to be used. Current AshNet field trials are likely to provide useful knowledge on the effects of industrial wood ash on forested sites, which might be of use for choosing dosage rates that would provide surplus Ca that could increase levels in ground and thus surface waters.

Implementation of any wood ash recycling programme to help solve the Ca decline problem would have to address issues such as ash collection, ash distribution to forested areas (e.g., manual vs. mechanical, or aerial spreaders), dosage rates, ash storage, frequency, and methods of application. Resolving these issues can help to save money by increasing waste diversion from to municipal landfills (Hope et al. 2017) and benefit the environment. With the exception of dosage rates, these are largely not ecotoxicological issues, but economic, logistical and engineering issues, and quite daunting ones at that. Once the ecotoxicological issues are resolved, they will require lots of enlightened discussion with waste management authorities and contractors if we are to develop a residential wood ash recycling programme to help solve the environmental problem of Ca decline.

\section{Conclusion}

The continuous decline of $\mathrm{Ca}$ concentrations in surface water is disrupting the ecology of lakes of central Ontario and low Ca concentrations in soils are limiting forest growth of some regional forests. One possible solution to combatting this issue is to supplement watershed soils with Ca. Our study has demonstrated that aside from crushed limestone and industrial wood ash, NIWA may be a viable option. Large quantities are readily available during the heating season. Although NIWA contains several trace metals of concern to regulatory authorities, the majority of these levels were below the CM1 target, the threshold for unrestricted land use application in Ontario. Thus, NIWA application 
is unlikely to increase metal concentrations in watershed soils to levels that might negatively impact Muskoka's forests and lakes. Although there is evidence of short-term toxic effects from high levels of $\mathrm{K}$, we think that this toxicity would dissipate rapidly, and the residual ash that sank to lake bottoms would not be toxic. However, given the great solubility of $\mathrm{K}$ minerals in the ash, and the presence of $\mathrm{P}$, which can pose an eutrophication risk, initial monitoring for metals and other elements in the landscapes receiving ash, and a large plot-scale study is recommended.

The implementation of a wood ash recycling programme may help to combat Ca decline and limitation. Such a programme would encourage residents of Muskoka and the province of Ontario to become "gardeners" and not "miners" of the forest. From our estimates, enough NIWA is available in Ontario to make a difference. In the initial stages, the wood ash recycling programme could focus mainly on residential ash, which is unlikely to negatively impact Muskoka's natural environment. Small businesses that use wood as a heating source could also be included in the programme once their wood ash has been analysed for metals, $\mathrm{K}$, and $\mathrm{P}$ concentrations. As there is $28 \%$ as much NIWA as industrial wood ash in Canada, researching it appears worthwhile. With the first step of ecotoxicological work completed, it is now time to collectively tackle the diversity of other considerations (e.g., application rates and frequency, proof of benefits, site specific dose requirements, logistics, distribution (e.g., wood ash pelletization), policy implications, and economics of broad-scale wood ash recycling) required to combat $\mathrm{Ca}$ decline.

\section{Acknowledgements}

We thank the nine local, permanent residents and one wood-fired pizza bakery that provided the wood ash for our study. We also thank Dean Haydon, our laboratory assistant, who assisted with all the work, and the Ontario Ministry of Environment and Climate Change (now the Ontario Ministry of Environment, Conservation and Parks), Dorset Environmental Science Centre and its staff and interns for logistical support, assistance, water chemistry analyses, and advice. This study was supported by a 2017 Ontario Trillium Foundation Seed Grant to Friends of the Muskoka Watershed and by NSERC funding to both Norman D. Yan and Shelley E. Arnott.

\section{Author contributions}

SSEA and NDY conceived and designed the study. SSEA performed the experiments/collected the data. SSEA, NDY, and SEA analyzed and interpreted the data. NDY, MPC-S, SEA, JAR, and PS contributed resources. SSEA, NDY, MPC-S, SEA, JAR, and PS drafted or revised the manuscript.

\section{Competing interests}

The authors have declared that no competing interests exist.

\section{Data availability statement}

All relevant data are within the paper and in the Supplementary Material.

\section{Supplementary materials}

The following Supplementary Material is available with the article through the journal website at doi:10.1139/facets-2018-0026.

Supplementary Material 1

Supplementary Material 2 


\section{References}

Aherne J, Dillon PJ, and Cosby BJ. 2003. Acidification and recovery of aquatic ecosystems in south central Ontario, Canada: regional application of the MAGIC model. Hydrology and Earth System Sciences, 7(4): 561-573. DOI: 10.5194/hess-7-561-2003

Altshuler I, Bemiri B, Xu S, Constantin A, Yan ND, and Critescu ME. 2011. An integrated multidisciplinary approach for studying multiple stressors in freshwater ecosystems: Daphnia as a model organism. Integrated \& Comparative Biology, 51(4): 623-633. PMID: 21873644 DOI: 10.1093/icb/icr103

Ashforth D, and Yan ND. 2008. The interactive and effects of calcium concentration and temperature on the survival of Daphnia pulex at high and low food concentrations. Limnology and Oceanography, 53(2): 420-432. DOI: 10.4319/10.2008.53.2.0420

AshNet. 2018. Canadian wood ash chemistry database [online]: Available from nrcan.gc.ca/forests/ research-centres/glfc/ashnet/20288.

Augusto L, Bakker MR, and Meredieu C. 2008. Wood ash applications to temperate forest ecosystems-potential benefits and drawbacks. Plant and Soil, 306(1-2): 181-198. DOI: 10.1007/ s11104-008-9570-Z

Azan S. 2017. Could a residential wood ash recycling programme help solve the calcium decline problem: insights from a Muskoka wood burner's questionnaire. Friends of the Muskoka Watershed Technical Report \#1. Bracebridge, Ontario. 20 p.

Azan S. 2018. Is residential wood ash safe for use to help solve the calcium decline problem in Muskoka? Friends of the Muskoka Watershed Technical Report \#2. Bracebridge, Ontario. 80 p.

Bailey SW, Horsley SB, Long RP, and Hallett RA. 2004. Influence of edaphic factors on sugar maple nutrition and health on the Allegheny Plateau. Soil Science Society of America Journal, 68(1): 243-252. DOI: 10.2136/sssaj2004.2430

Baird DJ, Barber I, Bradley M, Soares AMVM, and Calow P. 1990. A comparative study of genotype sensitivity to acute toxic stress using clones of Daphnia magna straus. Ecotoxicology and Environmental Safety, 21(3): 257-265. PMID: 1868782 DOI: 10.1016/0147-6513(91)90064-V

Baylor ER. 1942. Cardiac pharmacology of the cladoceran, Daphnia. The Biological Bulletin, 83(2): 165-172. DOI: $10.2307 / 1538141$

Biesinger KE, and Christensen GM. 1972. Effects of various metals on survival, growth, reproduction, and metabolism of Daphnia magna. Journal of the Fisheries Research Board of Canada, 29(12): 1691-1700. DOI: 10.1139/f72-269

Bishop DA, Beier CM, Pederson N, Lawrence GB, Stella JC, and Sullivan TJ. 2015. Regional growth decline of sugar maple (Acer saccharum) and its potential causes. Ecosphere, 6(10): 179. DOI: $10.1890 / \mathrm{ES} 15-00260.1$

Celis-Salgado MP, Cairns A, Kim N, and Yan ND. 2008. The FLAMES medium: a new, soft-water culture and bioassay medium for Cladocera. Verhandlungen des Internationalen Verein Limnologie, 30(2): 265-271. DOI: 10.1080/03680770.2008.11902123

Cleavitt NL, Fahey TJ, and Battles JJ. 2011. Regeneration ecology of sugar maple (Acer saccharum): seedling survival in relation to nutrition, site factors, and damage by insects and pathogen. Canadian Journal of Forest Research, 41(2): 235-244. DOI: 10.1139/X10-210 
Couillard Y, Cattaneo A, Gallon C, and Courcelles M. 2008. Sources and chronology of fifteen elements in the sediments of lakes affected by metal deposition in a mining area. Journal of Paleolimnology, 40(1): 97-114. DOI: 10.1007/s10933-007-9146-6

Demeyer A, Voundi Nkana JC, and Verloo MG. 2001. Characteristics of wood ash and influence on soil properties and nutrient uptake: an overview. Bioresource Technology, 77(3): 287-295. PMID: 11272014 DOI: 10.1016/S0960-8524(00)00043-2

Dillon PJ, and Rigler FH. 1975. A simple method for predicting the capacity of a lake for development based on lake trophic status. Journal of the Fisheries Research Board of Canada, 32(9): 1519-1531. DOI: $10.1139 / 175-178$

Dortwegt R, and Maughan EV. 2001. The chemistry of copper in water and related studies planned at the advanced photon source. In Proceedings of the 2001 Particle Accelerator Conference, Chicago, Illinois, 18-22 June 2001. pp. 1456-1458 [online]: Available from accelconf.web.cern.ch/accelconf/ p01/PAPERS/TPAH106.PDF.

Doucet A, Savard MM, Bégin C, Marion J, Smirnoff A, and Ouarda TBMJ. 2012. Combining tree-ring metal concentrations and lead, carbon and oxygen isotopes to reconstruct peri-urban atmospheric pollution. Tellus B: Chemical and Physical Meteorology, 64(1): 19005. DOI: 10.3402/tellusb.v64i0.19005

Driscoll CT, Cirmo CP, Fahey TJ, Blette VL, Bukaveckas PA, Burns DA, et al. 1996. The experimental watershed liming study: comparison of lake and watershed neutralization strategies. Biogeochemistry, 32(3): 143-174. DOI: 10.1007/BF02187137

Edwards BA, Jackson DA, and Somers KM. 2009. Multispecies crayfish declines in lakes: implications for species distributions and richness. Journal of the North American Benthological Society, 28(3): 719-732. DOI: 10.1899/08-148.1

Eimers MC, Hillis NP, and Watmough SA. 2018. Phosphorus deposition in a low phosphorus landscape: sources, accuracy, and contribution to declines in surface water P. Ecosystems, 21(4): 782-794. DOI: $10.1007 /$ s10021-017-0184-2

Elliott A, and Mahmood T. 2006. Beneficial uses of pulp and paper power boiler ash residues. Tappi Journal, 5(10): 9-16.

Environment Canada. 1990. Biological test method: acute lethality test using Daphnia spp. Environmental Protection Series. Report EPS1/RM/11 [online]: Available from publications.gc.ca/ site/eng/453426/publication.html.

Gavin DG, Beckage B, and Osborne B. 2009. Forest dynamics and the growth decline of red spruce and sugar maple on Bolton Mountain, Vermont: a comparison of modeling methods. Canadian Journal of Forest Research, 38(10): 2635-2649. DOI: 10.1139/X08-106

Geary RJ, and Driscoll CT. 1996. Forest soil solutions: acid/base chemistry and response to calcite treatment. Biogeochemistry, 32(3): 195-220. DOI: 10.1007/BF02187139

Government of Ontario. 2002. Ontario regulation 267/03 under the Nutrient Management Act [online]: Available from ontario.ca/laws/regulation/030267.

Hadley KR, Paterson AM, Reid RA, Rusak JA, Somers KM, Ingram R, et al. 2015. Altered pH and reduced calcium levels drive near extirpation of native crayfish, Cambarus bartonii, in Algonquin Park, Ontario, Canada. Freshwater Science, 34(3): 918-932. DOI: 10.1086/681910 
Hallett RA, Bailey SW, Horsley SB, and Long RP. 2006. Influence of nutrition and stress on sugar maple at a regional scale. Canadian Journal of Forest Research, 36(9): 2235-2246. DOI: 10.1139/ x06-120

Hannam KD, Deschamps C, Kwiaton M, Venier L, and Hazlett PW. 2016. Regulations and guidelines for the use of wood ash as a soil amendment in Canadian forests. Information Report No. GLC-X-17. Natural Resources Canada, Canadian Forestry Service, Sault Ste. Marie, Ontario [online]: Available from cfs.nrcan.gc.ca/pubwarehouse/pdfs/37781.pdf.

Hannam KD, Venier L, Allen D, Deschamps C, Hope E, Jull M, et al. 2018. Wood ash as a soil amendment in Canadian forests: what are the barriers to utilization? Canadian Journal of Forest Research, 48(4): 442-450. DOI: 10.1139/cjfr-2017-0351

Hope ES, McKenney DW, Allen DJ, and Pedlar JH. 2017. A cost analysis of bioenergy-generated ash disposal options in Canada. Canadian Journal of Forest Research, 47(9): 1222-1231. DOI: 10.1139/ cjfr-2016-0524

Jarvis AP, Mayes WM, Coulon P, Fox A, Hill S, Johnson D, et al. 2012. Prioritisation of abandoned non-coal mine impacts on the environment: future management of abandoned non-coal mine water discharges. Environment Agency Technical Report, Environment Agency, Horizon House, Deanery Road, Bristol. 71 p. DOI: 10.13140/2.1.1606.3524

Jeziorski A, Yan ND, Paterson AM, DeSellas AM, Turner MA, Jeffries DS, et al. 2008. The widespread threat of calcium decline in fresh waters. Science, 322(5906): 1374-1377. PMID: 19039134 DOI: $10.1126 /$ science.1164949

Jeziorski A, Paterson AM, and Smol JP. 2012. Changes since the onset of acid deposition among calcium-sensitive cladoceran taxa within soft water lakes of Ontario, Canada. Journal of Paleolimnology, 48(2): 323-337. DOI: 10.1007/s10933-012-9600-y

Jeziorski A, Tanentzap AJ, Yan ND, Paterson AM, Palmer ME, Korosi JB, et al. 2015. The jellification of north temperate lakes. Proceedings of the Royal Society B: Biological Sciences, 282(1798): 20142449. PMID: 25411451 DOI: 10.1098/rspb.2014.2449

Korosi JB, Burke SM, Thienpont JR, and Smol JP. 2012. Anomalous rise in algal production linked to lake water calcium decline through food web interactions. Proceedings of the Royal Society B: Biological Sciences, 279(1731): 1210-1217. PMID: 21957138 DOI: 10.1098/rspb. 2011.1411

Landre AL, Watmough SA, and Dillon PJ. 2010. Metal pools, fluxes, and budgets in an acidified forested catchment on the Precambrian Shield, central Ontario, Canada. Water, Air, \& Soil Pollution, 209(1-4): 209-228. DOI: 10.1007/s11270-009-0193-7

Lawrence GB, Burns DA, and Riva-Murray K. 2016. A new look at liming as an approach to accelerate recovery from acidic deposition effects. Science of the Total Environment, 562: 35-46. PMID: 27092419 DOI: $10.1016 / j . s c i t o t e n v .2016 .03 .176$

Likens GE, Driscoll CT, and Buso DC. 1996. Long-term effects of acid rain: response and recovery of a forest ecosystem. Science, 272(5259): 244-246. DOI: 10.1126/science.272.5259.244

Likens GE, Driscoll CT, Buso DC, Siccama TG, Johnson CE, Lovett GM, et al. 1998. The biogeochemistry of calcium at Hubbard Brook. Biogeochemistry, 41(2): 89-173. DOI: 10.1023/ A:1005984620681 
Löfgren S, Cory N, Zetterberg T, Larsson P-E, and Kronnäs V. 2006. The long-term effects of catchment liming and reduced sulphur deposition on forest soils and runoff chemistry in southwest Sweden. Forest Ecology and Management, 258(5): 567-578. DOI: 10.1016/j.foreco. 2009.04.030

Long RP, Horsley SB, Hallett RA, and Bailey SW. 2009. Sugar maple growth in relation to nutrition and stress in the northeastern United States. Ecological Applications, 19(6): 1454-1466. PMID: 19769094 DOI: 10.1890/08-1535.1

Mainwaring DB, Maguire DA, and Perakis SS. 2014. Three-year growth response of young Douglasfir to nitrogen, calcium, phosphorus, and blended fertilizers in Oregon and Washington. Forest Ecology and Management, 327: 178-188. DOI: 10.1016/j.foreco.2014.05.005

McLaughlin JW. 2014. Forest soil calcium dynamics and water quality: implications for forest management planning. Soil Science Society of America Journal, 78(3): 1003-1020. DOI: 10.2136/ sssaj2013.11.0474

Miller DE, and Watmough SA. 2009. Air pollution, climate, soil acidity, and indicators of forest health in Ontario's sugar maple forests. Canadian Journal of Forest Research, 39(11): 2065-2079. DOI: $10.1139 / \mathrm{X} 09-124$

Moore J-D, and Ouimet R. 2010. Effects of two Ca fertilizer types on sugar maple vitality. Canadian Journal of Forest Research, 40(10): 1985-1992. DOI: 10.1139/X10-136

Moore J-D, and Ouimet R. 2014. Effects of two types of Ca fertilizer on sugar maple nutrition, vigor and growth after 7 years. Forest Ecology and Management, 320: 1-5. DOI: 10.1016/j.foreco. 2014.02.017

Naik TR, Kraus RN, and Kumar R. 2001. Wood ash: a new source of pozzolanic material. Report No. CBU-2001-10, Center for By-products Utilization, University of Wisconsin-Milwaukee, Milwaukee, Wisconsin [online]: Available from www4.uwm.edu/cbu/Papers/2001\%20CBU\%20Reports/CBU\% 202001-10.pdf.

Naylor LM, and Schmidt EJ. 1986. Agricultural use of wood ash as a fertilizer and liming material. Tappi Journal, 69(10): 114-119.

Nicholls KH, and Cox CM. 1978. Atmospheric nitrogen and phosphorus loading to Harp Lake, Ontario, Canada. Water Resources Research, 14(4): 589-592. DOI: 10.1029/WR014i 004p00589

Pitman RM. 2006. Wood ash use in forestry-a review of environmental impacts. Forestry, 79(5): 563-588. DOI: 10.1093/forestry/cpl041

Pratte S, Mucci A, and Garneau M. 2013. Historical records of atmospheric metal deposition along the St. Lawrence Valley (eastern Canada) based on peat bog cores. Atmospheric Environment, 79: 831-840. DOI: 10.1016/j.atmosenv.2013.07.063

Pugliese S, Jones T, Preston MD, Hazlett P, Tran H, and Basiliko N. 2014. Wood ash as a forest soil amendment: the role of boiler and soil type on soil property response. Canadian Journal of Soil Science, 94(5): 621-634. DOI: 10.4141/cjss-2014-037

R Development Core Team. 2015. R: a language and environment for statistical computing. Version 3.2.3. R Foundation for Statistical Computing. Available from: r-project.org/. 
Reid C, and Watmough SA. 2014. Evaluating the effects of liming and wood-ash treatment on forest ecosystems through systematic meta-analysis. Canadian Journal of Forest Research, 44(8): 867-885. DOI: $10.1139 / c j f r-2013-0488$

Reid C, and Watmough SA. 2016. Spatial patterns, trends, and the potential long-term impacts of tree harvesting on lake calcium levels in the Muskoka River Watershed, Ontario, Canada. Canadian Journal of Fisheries and Aquatic Sciences, 73(3): 382-393. DOI: 10.1139/cjfas2015-0231

Sakwińska O. 2004. Persistent maternal identity effects on life history traits in Daphnia. Oecologia, 138(3): 379-386. PMID: 14655044 DOI: 10.1007/s00442-003-1434-X

Serafimova E, Mladenov M, Mihailova I, and Pelovski Y. 2011. Study on the characteristics of waste wood ash. Journal of the University of Chemical Technology and Metallurgy, 46: 31-34.

Skaug H, Fournier D, Nielsen A, Magnusson A, and Bolker B. 2016. glmmADMB. R package version 0.8.3.3 [online]: Available from glmmadmb.r-forge.r-project.org/.

Statistics Canada. n.d. Table 153-0145: households and the environment survey, primary heating systems, Canada, provinces and census metropolitan areas, every two years (percent), CANSIM database [online]: Available from www5.statcan.gc.ca/cansim/a26?lang=eng\&retrLang=eng\&id=1530145 \&pattern=\&csid.

Steenari BM, and Lindqvist O. 1997. Stabilisation of biofuel ashes for recycling to forest soil. Biomass and Bioenergy, 13(1-2): 39-50. DOI: 10.1016/S0961-9534(97)00024-X

Sullivan TJ, Lawrence GB, Bailey SW, McDonnell TC, Beier CM, Weathers KC, et al. 2013. Effects of acidic deposition and soil acidification on sugar maple trees in the Adirondack Mountains, New York. Environmental Science \& Technology, 47(22): 12687-12694. PMID: 24102084 DOI: 10.1021/ es401864w

The District Municipality of Muskoka. 2015-2016. Population: permanent and seasonal populations [online]: Available from muskoka.on.ca/en/work-and-invest/Population.aspx.

Vance ED. 1996. Land application of wood-fired and combustion boiler ashes: an overview. Journal of Environmental Quality, 25(5): 937-944. DOI: 10.2134/jeq1996.00472425002500050002x

Watmough SA. 2002. A dendrochemical survey of sugar maple (Acer saccharum Marsh) in southcentral Ontario, Canada. Water, Air, \& Soil Pollution, 136(1-4): 165-187. DOI: 10.1023/ A:1015231526980

Watmough SA. 2010. Assessment of the potential role of metals in sugar maple (Acer saccharum Marsh) decline in Ontario, Canada. Plant and Soil, 332(1-2): 463-474. DOI: 10.1007/ s11104-010-0313-6

Watmough SA, and Aherne J. 2008. Estimating calcium weathering rates and future lake calcium concentrations in the Muskoka-Haliburton region of Ontario. Canadian Journal of Fisheries and Aquatic Sciences, 65(5): 821-833. DOI: 10.1139/f07-196

Watmough SA, and Dillon PJ. 2003a. Calcium losses from a forested catchment in south-central Ontario. Environmental Science \& Technology, 37(14): 3085-3089. PMID: 12901654 DOI: 10.1021/ es034034t 
Watmough SA, and Dillon PJ. 2003b. Base cation and nutrient budgets for seven forested catchments in central Ontario, 1983-1999. Forest Ecology and Management, 177(1-3): 155-177. DOI: 10.1016/ S0378-1127(02)00320-1

Wilmot TR, Ellsworth DS, and Tyree MT. 1996. Base cation fertilization and liming effects on nutrition and growth of Vermont sugar maple stands. Forest Ecology and Management, 84(1-3): 123-134. DOI: 10.1016/0378-1127(96)03743-7

Yan ND, Keller W, Somers KM, Pawson TW, and Girard RE. 1996. Recovery of crustacean zooplankton communities from acidification: comparing manipulated and reference lakes. Canadian Journal of Fisheries and Aquatic Sciences, 53(6): 1301-1327. DOI: 10.1139/ f96-065 